\title{
Lipase mediated transesterification of Simarouba glauca oil: a new feedstock for biodiesel production
}

\author{
Vijay Kumar Garlapati ${ }^{1}$, Ravi Kant ${ }^{1}$, Annapurna Kumari ${ }^{1}$, Paramita Mahapatra ${ }^{1}$, Premananda Das ${ }^{2}$
} and Rintu Banerjee ${ }^{1^{*}}$

\begin{abstract}
Background: Immobilized lipase mediated tranesterification process for new feed stock Simarouba glauca oil for biodiesel production has been developed by utilizing the greener aspects of immobilized biocatalyst in $n$-hexane solvent system. The presence of solvent system helps to overcome the negative effects of methanol and glycerol, the end product. Effect of methanol to oil ratio, reaction time, methanol to hexane ratio, reaction temperature, agitation speed and immobilized lipase on final molar conversion were investigated.

Results: A maximum yield of $91.5 \%$ fatty acid methyl esters with a $62.23 \%$ molar conversion with respect to methyl oleate has been achieved with oil: methanol molar ratio of 1:1, using $10 \mathrm{U}$ of immobilized lipase/g of oil and with methanol to oil ratio of 1:0.6 in a reaction time of $36 \mathrm{~h}$ at $34{ }^{\circ} \mathrm{C}$ and $200 \mathrm{rpm}$. Immobilized lipase has been reused successfully up to 6 recycles with retaining relative activity of more than $95 \%$.

Conclusion: Lipase mediated tranesterification of new feedstock Simarouba glauca oil for biodiesel production has been successfully carried out under $n$-hexane solvent system. Utilization of immobilized lipase, which facilitates reuse helps considerably for the economy of the process. The introduced new feedstock with a green tinge seems to be a very promising to the biofuel sector for biodiesel production through sustainable approach.
\end{abstract}

Keywords: Fatty acid methyl esters, Immobilized lipase, Solvent free, Transesterification, Simarouba glauca oil

\section{Background}

Escalating oil prices and depletion of oil reserves necessitate better alternatives of energy from fossil fuels. With the rise in concern for pollution caused by fossil fuels such as petroleum, coal and natural gas, alternative fuels and renewable sources of energy such as biodiesel are coming in vogue [1]. Renewable fuels such as biodiesel is one of the potential contributors for solving the energy problem. Biodiesel is a biodegradable, non-toxic, and a low air pollutant emitting fuel than the petroleum diesel [2]. Biodiesel, which consists of fatty acid esters derived from oils of plant origin such as pongamia, mahwa, waste oils. Simarouba glauca (simaroubaceae) is an oil yielding tree native to South and Central American

\footnotetext{
* Correspondence: rb@iitkgp.ac.in

'Microbial Biotechnology and Downstream Processing Laboratory, Agricultural and Food Engineering Department, Indian Institute of Technology, Kharagpur, West Bengal 721302, India

Full list of author information is available at the end of the article
}

countries such as Costa Rica, El Salvador and brought to India by National Bureau of Plant Genetic Resources (NBPGR) and cultivating mainly in sub-humid climate of Orissa and semi arid, dry, saline land areas of other Indian states like Gujarat, Maharashtra, Tamilnadu, Karnataka and Andhra Pradesh. The oil produced by each Simarouba tree accounts per 1-2 $t$ oil per year grown under wide range of temperatures $\left(10-45^{\circ} \mathrm{C}\right)$ [3]. Owing to its 50-65\% oil content from seed part along with good amount of unsaturated fatty acid content (59-65\%, oleic acid) we have made an attempt to transesterify this Simarouba oil to biodiesel through biological green approach of immobilized lipase mediated transesterification [4]. It has a iodine value (IV) of $50-54 \%$ and saponification value of 191 with oleic acid as a predominant fatty acid [5]. IV provides a measure of unsaturated fatty acid content and helpful in determination of viscosity and cloud point. The recent research finding indicates that the
(C) Chemistry Central 
IV has no role in prediction of oxidative stability (as it does not take into account the positions of the double bonds available for oxidation) [6]. Having low IV values of Simarouba oil and that also in the range of standard specifications [EN14214 ( $\leq 120)$ and DIN $51606(\leq 115))$ ] corresponds for possible high cetane number, reduced NOx emissions and degradation potential of formed fatty acid methyl esters (FAME's) seems to be a better source for biodiesel through lipase mediated transesterification [7]. The usage of plant based oils clogs diesel engines due to their high viscosity. Among the existing methods (physical, chemical and biological), immobilized lipase mediated methanolysis of plant oils through transesterification has proven the most significant step towards making FAME's (biodiesel) due to the low cost of methanol, ecofriendly reaction conditions and the chemo-, regio- and enantiospecific nature of lipase [8]. Immobilized lipase mediated methanolysis involves lyses of plant oils into methyl esters and glycerol in presence of immobilized lipases [9].

Lipase-catalyzed transesterification of oils to FAME's gives a very high-purity product that can be easily separated from glycerol. The immobilized lipase can also be reused for multiple reactions and able to tolerate enzyme inhibitory effect of methanol and glycerol [10]. In particular, the glycerol can be easily removed without any complex process, while the free fatty acids contained in waste oils and fats can be completely converted to alkyl esters [11]. Transesterification variables such as methanol to oil ratio, reaction time, amount of solvent, temperature, addition of water, agitation, amount of immobilized enzyme are the critical factors affecting the FAME's yield [12]. The role of transesterification variables such as molar ratio of alcohol, temperature, type of catalyst on the final yield of transesrification has been reported in case of different plant based oils [13]. Several researchers reported the efficacy of covalently immobilized lipases in transesterification of different plant based oils and different aspects of the processes have been tested time and again. In another instance, free and covalently bound lipases were used for the alcoholysis of salicornia oil and obtained a methyl ester yield of $45 \%$ and $55 \%$ after $12 \mathrm{~h}$ with free and immobilized lipases respectively [14]. Dossat et al., 2002 [15] have studied the enzyme catalyzed transesterification of sunflower oil using immobilized Lipozyme. The optimal yield, as determined by methyl esters was $60 \%$ with respective to oleic acid. In another study, Du et al., 2004 [16] employed Novozyme 435 for the transesterification of crude soyabean oil and achieved a methyl ester yield of $94 \%$ in $120 \mathrm{~h}$.

Owing to its high content of oleic acid, in our present study Simarouba glauca oil have been evaluated first time for its feasibility as a biodiesel through immobilized lipase catalyzed transesterification reaction using n-hexane as a solvent. Based on the previous studies documentation towards high cost for utilization of pure lipase and its immobilization, in the present attempt a fungal lipase produced through cost effective solid state fermentation has been utilized and has been covalently immobilized on celite for its efficient utilization in the transesterification reaction.

\section{Results and discussion}

\section{Effect of methanol to oil ratio on transesterification}

Molar ratio of alcohol to vegetable oil is one of the important factors that affect the process conversion efficiency and the production cost of biodiesel. The transesterification reaction was carried out at different molar ratios as shown in Figure 1. The level of substrate molar ratio was selected by varying the methanol to oil ratio of 1:1-1:10 $\mathrm{M}$. The maximum conversion efficiency has been achieved with the molar ratio of 1:1 (Figure 1). Further increase in the methanol to oil ratio resulted in a decrease in the formation of esters. This may be due to the inhibitory effect of methanol on lipase activity $[17,18]$.

Li et al., 2006 [19] also reported the negative effect of higher methanol to oil molar ratio on methyl esters conversion. They achieved $95 \%$ yield of methyl esters of rape seed oil with methanol/oil molar ratio of $4: 1$ in 12 h. In another study by Royon et al., 2007 [20], a maximum yield of $97 \%$ methyl esters was achieved in transesterification of cottonseed oil using $13.5 \%$ methanol and $54 \%$ oil in $24 \mathrm{~h}$ at $50{ }^{\circ} \mathrm{C}$. The effect of methanol to oil ratio on the yield of methyl esters was reported by several researchers including immobilized lipase mediated methanolysis of soybean oil [21,22], jatropha oil [23] and canola oil [24]. In case of immobilized C. antarctica lipase mediated tranesterification of vegetable oil, a maximum conversion (95\%) was achieved with a methanol/oil molar ratio of 3:1 [25].

\section{Effect of reaction time on transesterification}

The effect of reaction time on the transesterification was investigated by varying the reaction time from $20-100 \mathrm{~h}$

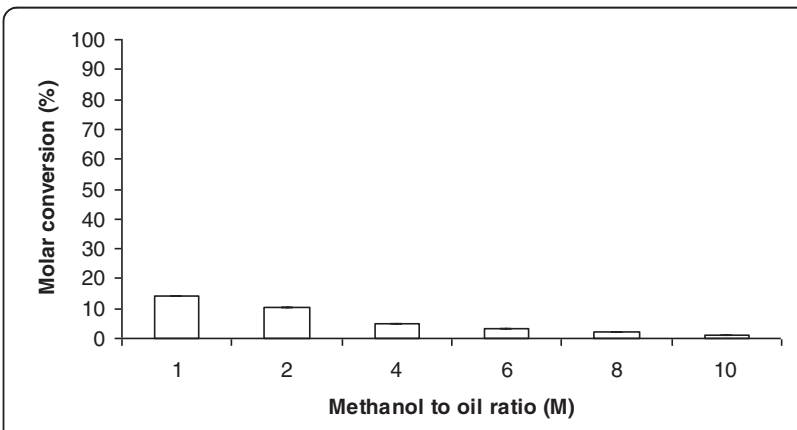

Figure 1 Effect of methanol to oil ratio on transesterification. All values are represented as mean \pm s.d of three replications. 
and has been shown in Figure 2. Results show that the rate of methanolysis was optimum at $36 \mathrm{~h}$ for Simarouba oil. After attainment of optimal reaction time, the lipase activity has been reported to be inhibited by methanol and glycerol [26]. Similar results were obtained in case of rapeseed and cottonseed oils transesterification, where the enhancement of methyl esters conversion was less after $12 \mathrm{~h}$ and $24 \mathrm{~h}$ respectively $[19,20]$. A maximum methyl esters conversion of $95 \%$ within 48 h by employing immobilized C. antarcitica lipase has been reported in methanolysis of vegetable oil [25].

\section{Effect of volume of solvent on transesterification}

Various amounts of hexane were added to the reaction system to study its effect on the ester formation (Figure 3). Different volume ratios (1:0.2-1:1 v/v) of alcohol to hexane were tested. The results show that reaction rate was higher when methanol to hexane volume ratio was 1:0.6 for Simarouba. For further increase in n-hexane concentration no increment in biodiesel synthesis was observed. The presence of n-hexane in specified amounts may have improved the solubility of methanol in the reaction mixture, so lipase still maintained high activity even with methanol present in the system (by addition of first methanol to oil and then the resultant solution to hexane). When the amount of n-hexane was enhanced further, the yield of methyl esters decreased gradually. This might have caused by the dilution effect of too much reactants present in the system [27]. Similar phenomenon was observed in case of lipase-catalyzed transesterification of high oleic sunflower oil and degummed soybean oil to biodiesel fuel $[15,28]$ catalyzed by immobilized Candida antarctica lipase. Iso et al., 2001 [29] obtained enhanced results in transesterification of safflower oil by immobilized $P$. fluroscence lipase and using 1, 4-Dioxane as a solvent.

\section{Effect of reaction temperature on tranesterification}

The increase in temperature speeds up the reaction rate upto certain extent after that the denaturation of the enzyme takes place due to the proteineous nature of the

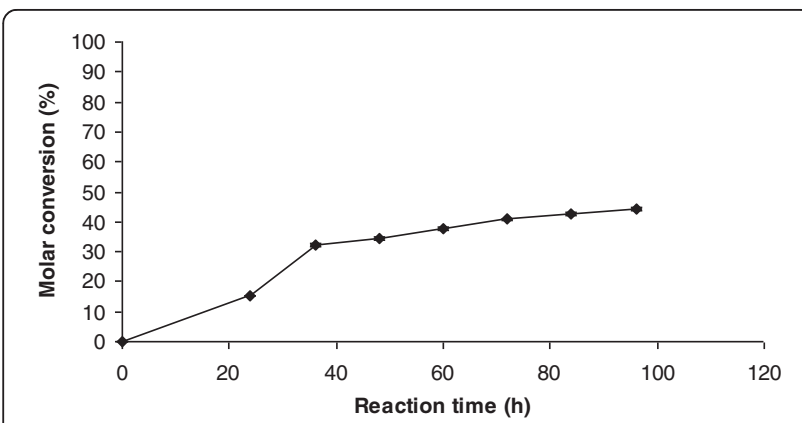

Figure 2 Effect of reaction time on transesterification. All values are represented as mean \pm s.d of three replications.

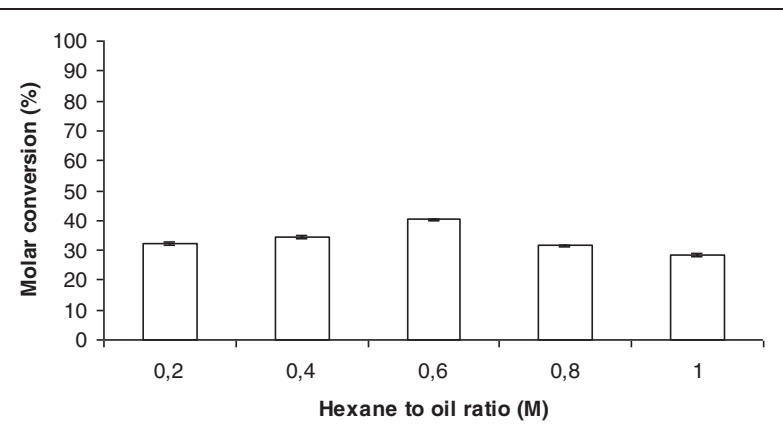

Figure 3 Effect of amount of solvent on transesterification. All values are represented as mean \pm s.d of three replications.

enzyme [29]. The effect of reaction temperature on transesterifcation was examined over the temperature range of $28-44{ }^{\circ} \mathrm{C}$ (Figure 4). The maximal molar conversion was achieved with the reaction temperature of $34{ }^{\circ} \mathrm{C}$ for Simarouba oil. The decrease in molar conversion after certain temperature could be attributed to the loss of activity through denaturation [30]. Denaturation of enzyme after certain temperature has been reported by several authors in transesterification of various oils. Kose et al., 2002 [31] obtained $91.5 \%$ methyl ester yield in transesterification of cottonseed oil at $50{ }^{\circ} \mathrm{C}$. In case of transesterification of Jatropha oil catalyzed by Pseudomonas cepacia lipase immobilized on celite an optimum ester yield was obtained at $50{ }^{\circ} \mathrm{C}$ [32]. Modi et al., 2007 [33] obtained a molar conversion of $91.3 \%, 90 \%$ and $92.7 \%$ in case of tranesterification of crude Jatropha, Karanja and Sunflower oils respectively by using Novozyme 435 lipase at $50{ }^{\circ} \mathrm{C}$.

\section{Effect of initial addition of water on transesterification}

The effect of initial addition of water on the transesterification reaction was investigated by varying the addition of water from $5-20 \%(\mathrm{v} / \mathrm{v})$ of the total amount of reaction mixture (Figure 5). With the addition of water, the molar conversion has been reduced in case of all oils. It was observed that the molar conversion was

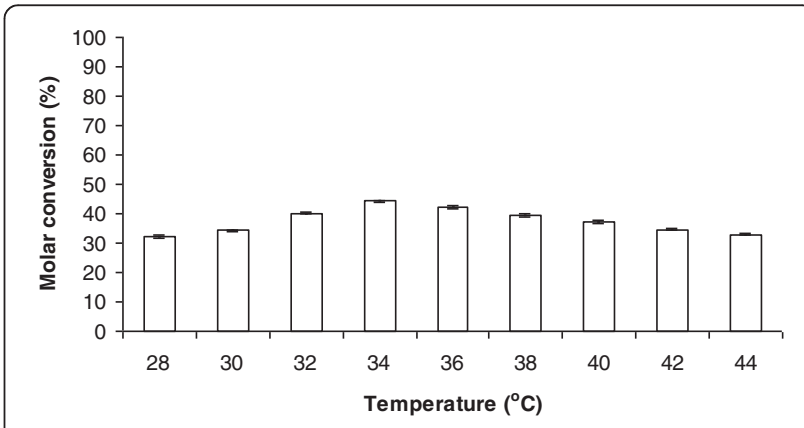

Figure 4 Effect of temperature on transesterification. All values are represented as mean \pm s.d of three replications. 


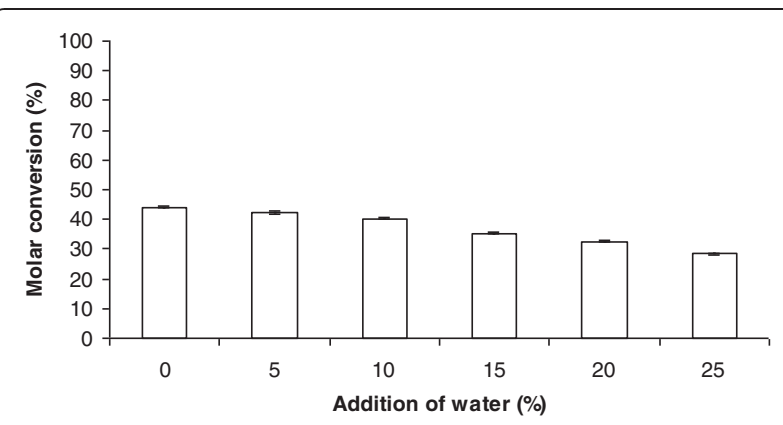

Figure $\mathbf{5}$ Effect of addition of water on transesterification. All values are represented as mean \pm s.d of three replications.

optimum when there was no additional water in the reaction mixture. In some enzymatic reactions, water is needed for acquisition and maintenance of enzymes' catalytically active conformation in anhydrous organic solvents. In the mean time, too much of water facilitates enzyme aggregation which leads to decrease in enzyme activity [34]. According to Klibanov, 1997 [35], the amount of water in the reaction mixture will determine the direction of lipase-catalyzed reaction. When there is little or no water, only esterification and transesterification are favored and when there is excess water in the reaction mixture, hydrolysis is the favored reaction when there is $[35,36]$. In the present study, maximum molar conversion has been observed without any added water in the reaction mixture irrespective of oils used. Similar results were reported in case of soyabean oil and triolein transesterification catalyzed by Mucor miehei and P. fluorescens lipases [29,37].

\section{Effect of agitation speed on tranesterification}

In the present study effect of agitation speed on the transeserification was studied in the range of 100$250 \mathrm{rpm}$ (Figure 6). The molar conversion has been found to increase with the increased agitation speed from 100-200 rpm with the optimum at $200 \mathrm{rpm}$. However, no further increase in molar conversion was

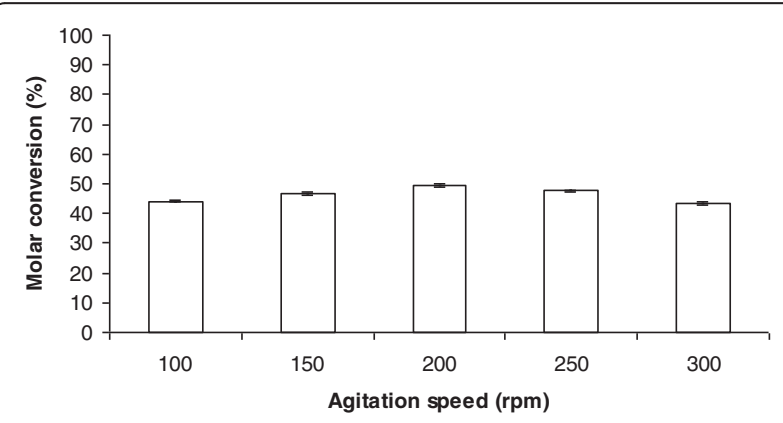

Figure 6 Effect of agitation speed on transesterification. All values are represented as mean \pm s.d of three replications. observed at $250 \mathrm{rpm}$, which might be due to shearing of enzyme molecules. Thus, the optimum speed for transesterification reaction was found to be $200 \mathrm{rpm}$. Agitation helps in the immobilized system to diffuse the reactants from the bulk liquid to the external surface of the particle and from there into the interior pores of the catalyst. Selection of optimum speed of agitation plays an important role in case of external mass transfer limitations [38].

\section{Effect of immobilized enzyme amount on tranesesterification}

The amount of enzyme used is a crucial economic factor for successful industrial application. Therefore, the effect of amount of enzyme on transesterification of oils was examined with the various amount of enzyme range from 2-15 U. The optimum molar conversion has been obtained using $10 \mathrm{U}$ for Simarouba oil (Figure 7). Moreover, the optimal molar conversion of $62.23 \%$ has been observed with respective to methyl oleate with $95 \%$ yield for Simarouba oil. A previous study by Ghamgui et al. 2004 [39], demonstrated that the yield of butyl esters increased to maximum by using $60 \mathrm{U}$ of Rhizopus oryzae lipase. Thereafter, the molar conversion remained almost constant with increase in lipase amount beyond $60 \mathrm{U}$. The maximum methyl ester yield was reported by Kose et al., 2002 with the $30 \%$ Novozyme based on oil weight in transesterification of cottonseed oil [31]. Similar results were reported in case of methanolysis of rice bran oil using Cryptopcoccus sp. S-2 lipase [40].

\section{Reusability of immobilized lipase}

The main advantage of immobilization of an enzyme is that an expensive enzyme can be repeatedly used. However, it was observed that reaction behavior changes when an immobilized enzyme is used repeatedly. The immobilized lipase was filtered at the end of the reaction, washed with t-butanol and again introduced with fresh reactants in order to study its operational stability

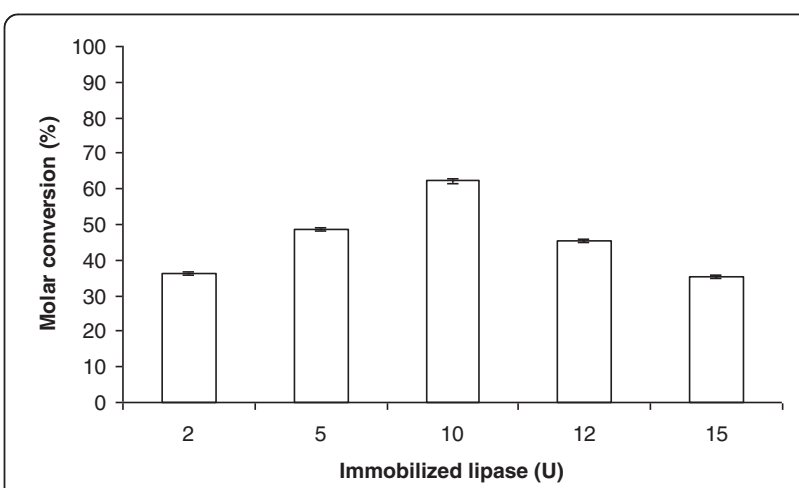

Figure 7 Effect of lipase amount on transesterification. All values are represented as mean \pm s.d of three replications. 
in each cycle. The immobilized enzyme has been reused upto 6 recycles for simarouba with retaining the relative activity more than $95 \%$ (Figure 8). The immobilized enzyme facilitates the reusability of the enzyme by employing in various cycles, thereby reducing the purification cost of the methyl esters and enzyme cost [26]. Pig pancreatic lipase immobilized on sepiolite showed a remarkable reusability of more than 11 successive runs without significant loss of enzyme activity [41]. In another study, Novozyme 435 maintained its activity over twelve repeated cycles with ethyl acetate but its activity reached zero by sixth cycle while using methanol as the alcohol [33]. P. cepacia lipase immobilized on celite maintained its activity up to 4 cycles in tranesterification of Jatropha oil [32]. In the present work, the methanolysis of Simarouba oil has been successfully carried out through immobilized lipase mediated transesterification. Further research and development on determination of fuel properties, engine performance tests and emitting profiles are also necessary.

\section{Experimental}

\section{Microorganism and chemicals}

A well known lipolytic fungal strain Rhizopus oryzae 3562 was isolated from the local soil of IIT Kharagpur and maintained on PDA (Potato Dextrose Agar) medium. $p$-nitrophenyl pamitate ( $p$-NPP), Methyl oleate standard were purchased from Sigma (USA). All chemicals used were of AR grade and were procured from Merck, Qualigens and Himedia, India.

\section{Production, immobilization of lipase}

Lipase was produced using wheat bran as a substrate through solid state fermentation as mentioned in our previous work [42]. Lipase immobilized on activated celite $(50 \mathrm{U} / \mathrm{g}$, data was not shown) through covalent immobilization was utilized for the present tranesterification reaction.

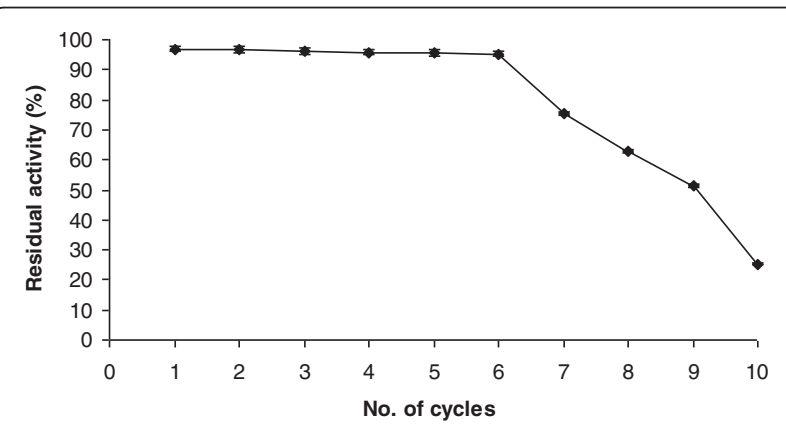

Figure 8 Reusability of immobilized lipase in transesterification of oils. All values are represented as \pm s.d of three replications.

\section{Lipase assay and protein determination}

Lipase assay was done spectrophotometrically using pNPP as the substrate. One unit (U) of enzyme is defined as the amount of enzyme that liberates one micromole of $p$-nitrophenol per minute under the assay conditions. Total protein was estimated using bovine serum albumin (BSA) as standard as described by Lowry et al. 1951 [43].

\section{Lipase mediated synthesis FAME's}

Simarouba glauca oil, methanol and solvent were taken in different ratios (oil to methanol molar ratios of 1:11:10 and methanol to solvent ratio's of 1:2 $-1: 10 \mathrm{v} / \mathrm{v}$ ) in a screw-capped vial. Immobilized lipase (20-100 U) was added to the reaction mixture and incubated at different temperatures $\left(25-45^{\circ} \mathrm{C}\right)$ and shaking rates $(100-300 \mathrm{rpm})$. The progress of reaction was monitored by withdrawing aliquots $(100 \mu \mathrm{l})$ at various time intervals $(12-96 \mathrm{~h})$. Samples taken from the reaction mixture at specified times were centrifuged at $1747 \mathrm{~g}$ for $10 \mathrm{~min}$ to remove the immobilized enzyme. They were then diluted with $n$-hexane (10 times) and analyzed by gas chromatography.

\section{GC analysis}

Methyl esters were analyzed by using Agilent 6820 Gas Chromatograph with a flame-ionization detector (USA). The capillary column (length $30 \mathrm{~m}$, internal diameter $0.25 \mathrm{~mm}$ ) with nitrogen as the carrier gas at a constant pressure of $4 \mathrm{~kg} \mathrm{~cm}^{2}$ was used. Column oven temperature was programmed from 150 to $250{ }^{\circ} \mathrm{C}\left(\right.$ at $10{ }^{\circ} \mathrm{C} \mathrm{min}^{-1}$ ) with injector and detector temperatures at 240 and $250{ }^{\circ} \mathrm{C}$, respectively. The \% molar conversion of products was identified by comparing the peak area of standard methyl oleate at the particular retention time.

\section{Conclusions}

Methanolysis of Simarouba oil with lipase immobilized covalently on celite to yield FAME's (biodiesel) through transesterification has been investigated. The effect of transesterification variables such as methanol to oil ratio, reaction time, volume of solvent, reaction temperature, initial addition of water, agitation speed and quantity of immobilized lipase on molar conversion (\%) was monitored. A maximum molar conversion of $62.23 \%$ with respect to methyl oleate (with $91.5 \%$ yield) was obtained after a reaction time of $36 \mathrm{~h}$ at $34{ }^{\circ} \mathrm{C}$ in the presence o $10 \mathrm{U}$ immobilized lipase using methanol to oil ratio of 1:1 and solvent to oil ratio of 1:0.6. The FAME's production was not influenced by the addition of water up to $20 \%(\mathrm{v} / \mathrm{v})$. The immobilized lipase was reusable for six cycles with retaining the relative activity of more than $95 \%$.

\section{Competing interests}

The authors declare that they have no competing interests. 


\section{Author's contributions}

VKG carried out the immobilized lipase mediated transesterification study of Simarouba oil. RK helped in lipase production. AK \& PM helped in the immobilization studies of lipase tasks. PD helped in extraction of oil from Simarouba glauca seeds. RB conceived of the study, and participated in its design and coordination. All authors read and approved the final manuscript.

\section{Acknowledgements}

The authors gratefully acknowledge MHRD, Govt of India for providing research fellowship to Vijay Kumar Garlapati \& Ravikant, CSIR, India for providing research scholarship to Annapurna Kumari.

\section{Author details}

${ }^{1}$ Microbial Biotechnology and Downstream Processing Laboratory, Agricultural and Food Engineering Department, Indian Institute of Technology, Kharagpur, West Bengal 721302, India. ${ }^{2}$ Venkateswar Institute for Sustainable, Innovative and Objective Nurture, Baramunda, Bhubaneswar 751003, India.

Received: 5 March 2013 Accepted: 26 June 2013

Published: 9 July 2013

\section{References}

1. Singh SP, Singh D: Biodiesel production through the use of different sources and characterization of oils and their esters as the substitute of diesel: a review. Renew Sust Energ Rev 2010, 14(1):200-216.

2. Abbaszaadeh A, Ghobadian B, Omidkhah MR, Najafi G: Current biodiesel production technologies: a comparative review. Energ Convers Manage 2012, 63:138-148.

3. Kaul S, Kumar A, Bhatnagar AK, Goyal HB, Gupta AK: Biodiesel: a clean \& sustainable fuel for future. IISC Bangalore: All India seminar on national policy on non-edible oils as biofuels; 2003.

4. Ghaly AE, Dave D, Brooks MS, Budge S: Production of biodiesel by enzymatic transesterification: review. Am J Biochem Biotechnol 2010, 6(2):54-76.

5. Govindaraju K, Darukeshwara J, Srivastava Alok K: Studies on protein characteristics and toxic constituents of Simarouba glauca oilseed meal. Food Chem Toxicol 2009, 47(6):1327-1332.

6. Caye D, John N, Terry W: Biofuels engineering processing technology. USA: The McGraw-Hill Companies; 2008.

7. Rao PV, Clarke S, Brown R: Influence of iodine value on combustion and NOx emission characteristics of a Dl diesel engine. Adelaide, South Australia: Chemeca 2010: The 40th Australasian Chemical Engineering Conference; 2010.

8. Fan X, Niehus X, Sandoval G: Lipases as biocatalyst for biodiesel production. Method Mol Biol 2012, 861:471-483.

9. Bajaj A, Lohan P, Jha PN, Mehrotra R: Biodiesel production through lipase catalyzed transesterification: an overview. J Mol Catal B: Enzym 2010, 62(1-2):9-14

10. Gog A, Roman M, Toşa M, Paizs C, Irimie FD: Biodiesel production using enzymatic transesterification - current state and perspectives. Renew Energ 2012, 39(1):10-16.

11. Macario A, Moliner M, Diaz U, Jorda JL, Corma A, Giordano G: Biodiesel production by immobilized lipase on zeolites and related materials. Stud Surf Sci Catal 2008, 174(2):1011-1016

12. Tan T, Lu J, Nie K, Deng L, Wang F: Biodiesel production with immobilized lipase: a review. Biotechnol Adv 2010, 28(5):628-634.

13. Da Rós PCMD, Silva GAM, Mendes AA, Santos JC, Castro HFD: Evaluation of the catalytic propertied of Burkholderia cepacia lipase immobilized on non-commercial matrices to be used in biodiesel synthesis from different feedstock's. Bioresource Technol 2010, 101(14):5508-5516.

14. Desai PD, Dave AM, Devi S: Alcoholysis of salicornia oil using free and covalently bound lipase onto chitosan beads. Food Chem 2006, 95:193-199.

15. Dossat V, Combes D, Marty A: Lipase-catalyzed transesterification of high oleic sunflower oil. Enzyme Microbiol Technol 2002, 30:90-94.

16. Du W, Xu Y, Liu D, Zeng J: Comparative study on lipase-catalyzed transformation of soybean oil for biodiesel production with different acyl acceptors. J Mol Catal B: Enzym 2004, 30(3-4):125-129.

17. Lu J, Deng L, Zhao R, Zhang R, Wang F, Tan T: Pretreatment of immobilized Candida sp. 99-125 lipase to improve its methanol tolerance for biodiesel production. J Mol Catal B: Enzym 2010, 62(1):5-18.

18. Bousquet-Dubouch MP, Graber M, Sousa N, Lamare S, Legoy MD: Alcoholysis catalyzed by Candida antarctica lipase B in a gas/solid system obeys a Ping Pong Bi Bi mechanism with competitive inhibition by the alcohol substrate and water. Biochim Biophys Acta Protein Struct Mol Enzymol 2001, 1550(1):90-99.

19. Li L, Du W, Liu D, Wang L, Li Z: Lipase-catalyzed transesterification of rapeseed oils for biodiesel production with a novel organic solvent as the reaction medium. J Mol Catal B: Enzym 2006, 43(1-4):58-62

20. Royon D, Daz M, Ellenrieder G, Locatelli S: Enzymatic production of biodiesel from cotton seed oil using t-butanol as a solvent. Bioresource Technol 2007, 98(3):648-653.

21. Kaieda M, Samukawa T, Kondo A, Fukuda H: Effect of methanol and water contents on production of biodiesel fuel from plant oil catalyzed by various lipases in a solvent-free system. J Biosci Bioeng 2001, 91:12-15.

22. Noureddini H, Gao X, Phikana RS: Immobilized Pseudomonas cepacia lipase for biodiesel fuel production from Soyabean oil. Bioresource Technol 2005, 96:769-777.

23. Kumari A, Mahapatra P, Garlapati VK, Banerjee R: Enzymatic transesterification of Jatropha oil. Biotechnol Biofuels 2009, 2:1.

24. Dizge N, Keskinler B: Enzymatic production of biodiesel from canola oil using immobilized lipase. Biomass Bioenerg 2008, 32(12):1274-1278.

25. Shimada $Y$, Watanabe $Y$, Samukawa $T$, Sugihara A, Noda $H$, Fukuda $H$, Tominaga Y: Conversion of vegetable oil to biodiesel using immobilized Candida antarctica lipase. J Am Oil Chem Soc 1999, 76:789-793.

26. Fukuda $\mathrm{H}$, Kondo $\mathrm{A}$, Noda $\mathrm{H}$ : Biodiesel fuel production by transesterification of oils. J Biosci Bioeng 2001, 92(5):405-416.

27. Freedman B, Pryde EH, Mounts TL: Variables affecting the yields of fatty esters from tranesterified vegetable oils. J Am Oil Chem Soc 1984, 61:1638-1643.

28. Watanabe $Y$, Shimada Y, Sugihara A, Tominaga Y: Conversion of degummed soybean oil to biodiesel fuel with immobilized Candida antarctica lipase. J Mol Catal B: Enzym 2002, 17(3-5):151-155.

29. Iso M, Chen B, Eguchi M, Kudo T, Shrestha S: Production of biodiesel fuel from triglycerides and alcohol using immobilized lipase. J Mol Catal B: Enzym 2001, 16:53-58.

30. Meher LC, Vidya Sagar D, Naik SN: Technical aspects of biodiesel production by transesterification-a review. Renew Sust Energ Rev 2006, 10(3):248-268.

31. Kose O, Tuter M, Aksoy HA: Immobilized Candida antarctica lipasecatalyzed alcoholysis of cotton seed oil in a solvent-free medium. Bioresource Technol 2002, 83(2):125-129.

32. Shah S, Gupta MN: Lipase catalyzed preparation of biodiesel from Jatropha oil in a solvent free system. Proc Biochem 2007, 42(3):409-414.

33. Modi MK, Reddy JRC, Rao BVSK, Prasad RBN: Lipase-mediated conversion of vegetable oils into biodiesel using ethyl acetate as acyl acceptor. Bioresource Technol 2007, 98(6):1260-1264

34. Volkin DB, Staubli A, Langer R, Klibanov AM: Enzyme thermo inactivation in anhydrous organic solvents. Biotechnol Bioeng 1991, 37:843-853.

35. Klibanov AM: Why are enzymes less active in organic solvents than in water? Trends Biotechnol 1997, 15:97-101.

36. Sharma $R$, Chisti $Y$, Banerjee UC: Production, purification, characterization, and applications of lipases. Biotechnol Adv 2001, 19:627-662.

37. Nelson LA, Foglia TA, Marmer WN: Lipase catalyzed production of biodiesel. J Am Oil Chem Soc 1996, 73:1191-1195.

38. Yadav GD, Trivedi AH: Kinetic modeling of immobilized-lipase catalyzed transesterification of n-octanol with vinyl acetate in non-aqueous media. Enzyme Microb Technol 2003, 2(7):783-789

39. Ghamgui H, Karra-châabouni M, Gargouri Y: 1-Butyl oleate synthesis by immobilized lipase from Rhizopus oryzae: a comparative study between n-hexane and solvent-free system. Enzyme Microb Tech 2004, 35:355-363.

40. Kamini NR, lefuji $\mathrm{H}$ : Lipase catalyzed methanolysis of vegetable oils in aqueous medium by Cryptococcus spp. S-2. Process Biochem 2001, 37(4):405-410.

41. Caballero V, Bautista FM, Campelo JM, Luna D, Marinus JM, Romero AA, Hidalgo JM, Luque R, Macario A, Giordano G: Sustainable preparion of a novel glycerol-free biofuel by using pig pancreatic lipase: Partial 1,3-regiospecific alcoholysis of sunflower oil. Process Biochem 2009, 44(2-3):334-342.

42. Garlapati VK, Banerjee R: Evolutionary and swarm intelligence based approaches for optimization of lipase extraction from fermented broth Eng Life Sci 2010, 10(3):1-9.

43. Lowry OH, Rosebrough NJ, Farr AL, Randall RJ: Protein measurement with folin phenol reagent. J Biol Chem 1951, 193:265-275.

doi:10.1186/2043-7129-1-11

Cite this article as: Garlapati et al.: Lipase mediated transesterification of Simarouba glauca oil: a new feedstock for biodiesel production. Sustainable Chemical Processes 2013 1:11. 